\title{
ALGORITME STACKING UNTUK KLASIFIKASI PENYAKIT JANTUNG PADA DATASET IMBALANCED CLASS
}

\author{
Atik Nurmasani ${ }^{1}$, Yoga Pristyanto ${ }^{2}$ \\ 1,2 Sistem Informasi. Fakultas Ilmu Komputer, Universitas Amikom Yogyakarta \\ Jl. Ring Road Utara, Condong Catur Sleman, Yogyakarta (telp: 0274-884201-207; 0274-884208) \\ ${ }^{1}$ nurmasaniepertama.ac.id \\ ${ }^{2}$ yoga.pristyanto@amikom.ac.id
}

\begin{abstract}
Abstrak: Berdasarkan data Riset Kesehatan Dasar (Riskesdas) tahun 2018, angka kejadian penyakit jantung dan pembuluh darah semakin meningkat dari tahun ke tahun. Setidaknya, 15 dari 1000 orang, atau sekitar 2.784.064 individu di Indonesia menderita penyakit jantung. Data mining merupakan bidang yang dapat menjadi solusi untuk digunakan sebagai alat deteksi dini penyakit jantung. Pada penelitian yang dilakukan sebelumnya mayoritas menggunakan single classifier, hal ini akan menimbulkan sebuah permasalahan baru ketika dalam dataset penyakit terdapat ketidakseimbangan kelas. Keberadaan ketidakseimbangan tersebut dapat menyebabkan kinerja single classifier menjadi tidak maksimal. Oleh karena itu pada penelitian ini akan digunakan metode ensemble atau meta learning. Berdasarkan pengujian yang dilakukan menunjukkan bahwa algoritme stacking mampu menghasilkan kinerja dari sisi akurasi TPR, TNR, G-Mean dan AUC yang lebih baik dibandingkan single classifier lainnya. Dengan adanya peningkatan nilai tersebut diharapkan penelitian ini mampu menjadi referensi untuk pengembangan berbagai sistem yang mendukung dan memaksimalkan tingkat keberhasilan proses deteksi dini penyakit jantung menggunakan data mining.
\end{abstract}

Kata Kunci: Data Mining, Stacking, Penyakit Jantung, Imbalaced Class, Ensemble, Klasifikasi.

Abstract: Based on data from Basic Health Research (Riskesdas) in 2018, the incidence of heart and blood vessel disease has increased from year to year. At least, 15 out of 1000 people or about 2,784,064 individuals in Indonesia suffer from heart disease. Data mining is a field that can be a solution to be used as an early detection tool for heart disease. In previous research, the majority used a single classifier, this would create a new problem when the disease dataset contained class imbalances. The existence of this imbalance can cause the performance of the single classifier to be not optimal. Therefore, this study will use the ensemble or meta-learning method. Based on the tests conducted, it shows that the stacking algorithm can produce better performance in terms of TPR, TNR, G-Mean, and AUC accuracy than other single classifiers. With this increase in value, it is hoped that this research can become a reference for the development of various systems that support and maximize the success rate of the early detection process of heart disease using data mining.
Keywords: Data Mining, Stacking, Heart Desease, Imbalaced Class, Ensemble, Classification

\section{PENDAhUluan}

Cardiovascular Diseases (CVD) merupakan salah satu penyakit mematikan nomor satu didunia. Berdasarkan laporan World Health Organization (WHO) angka kematian yang disebabkan oleh penyakit Cardiovascular Diseases (CVD) mencapai 17,7 juta orang setiap tahunnya dan $31 \%$ merupakan penyebab dari seluruh kematian global. Angka kematian akibat penyakit Cardiovascular Diseases diprediksi akan terus meningkat dari tahun ke tahun dan diperkirakan pada tahun 2030 akan mencapai 23,3 juta kematian [1] [2]. Salah satu penyakit Cardiovascular Diseases ialah 
Jurnal Pseudocode, Volume VIII Nomor 1, Februari 2021, ISSN 2355-5920, e-ISSN 2655-1845 www.ejournal.unib.ac.id/index.php/pseudocode

penyakit jantung. Berdasarkan data Riset data masa depan [7]. Beberapa algoritme Kesehatan Dasar (Riskesdas) tahun 2018, angka kejadian penyakit jantung dan pembuluh darah semakin meningkat dari tahun ke tahun. Setidaknya, 15 dari 1000 orang, atau sekitar 2.784.064 individu di Indonesia menderita penyakit jantung [3].

Pada dasarnya penyakit jantung dapat dicegah dengan berbagai faktor, diantaranya pola hidup sehat. Selain itu deteksi dini penyakit jantung juga diperlukan untuk mencegah terjadinya kematian pada penderitanya. Salah satu cara untuk melakukan deteksi dini ialah menggunakan teknologi informasi [4]. Data mining merupakan bidang yang dapat menjadi solusi untuk digunakan sebagai alat deteksi dini penyakit jantung. Data mining dapat diartikan sebagai berbagai macam cabang ilmu pengetahuan yang menjadi satu, terdiri atas sistem basis data, statistika, machine learning, visualization, dan informasi pengetahuan. Data mining telah berhasil diterapkan diberbagai bidang ilmu seperti ekonomi, bioinformatika, genetika, kedokteran, pendidikan dan lain sebagainya [5].

Pada data mining terdapat berbagai teknik antara lain klastering, asosiasi, prediksi dan klasifikasi [6]. Pada kasus deteksi dini penyakit jantung mayoritas teknik yang digunakan ialah klasifikasi. Teknik klasifikasi bekerja dengan mengenali pola atau model dari sebuah dataset khususnya dataset penyakit jantung yang sudah banyak tersedia di repository. Tujuannya agar model tersebut dapat digunakan untuk memprediksi ataupun klasifikasi apakah seseorang tersebut menderita penyakit jantung atau tidak. Model tersebut didasarkan pada analisis data latih. Model dari hasil klasifikasi dapat dimanfaatkan untuk mengklasifikasikan serta memprediksi tren

klasifikasi yang umum digunakan pada deteksi dini penyakit jantung menggunakan data mining antara lain K-Nearest Neighbour (kNN), Tree C4.5, Support Vector Machine (SVM) dan Neural Network (NN) [8]. Pada penelitian yang dilakukan sebelumnya mayoritas menggunakan single classifier, hal ini akan menimbulkan sebuah permasalahan baru ketika dalam dataset penyakit terdapat ketidakseimbangan kelas. Keberadaan ketidakseimbangan tersebut dapat menyebabkan kinerja single classifier menjadi tidak maksimal. Oleh karena itu pada penelitian ini akan digunakan metode ensemble atau meta learning. Metode ensemble merupakan gabungan dari beberapa algoritme yang dijadikan satu sehingga kinerjanya lebih baik dibandingkan single classifier. Algoritme ensemble yang digunakan pada penelitian ini ialah Stacking. Tujuannya ialah untuk meningkatkan kinerja single classifier. Dengan adanya peningkatan kinerja klasifikasi diharapkan dapat digunakan sebagai referensi, terutama dalam rangka pengembangan berbagai sistem yang dapat meningkatkan keberhasilan deteksi dini penyakit jantung menggunakan teknologi informasi.

\section{TINJAUAN PUSTAKA}

Berbagai penelitian telah dilakukan terkait deteksi dini penyakit jantung menggunakan data mining. Penelitian yang dilakukan oleh [9] menggunakan algoritme Support Vector Machine (SVM) dengan kernel linier menghasilkan akurasi sebesar $77 \%$ pada kasus klasifikasi penyakit jantung. Penelitian serupa juga dilakukan oleh [10] menggunakan algoritme SVM, Decision Tree, dan Neural Network. Masing-masing algoritme menghasilkan akurasi sebesar SVM 69\%, Decision 
Jurnal Pseudocode, Volume VIII Nomor 1, Februari 2021, ISSN 2355-5920, e-ISSN 2655-1845 www.ejournal.unib.ac.id/index.php/pseudocode

Tree $70 \%$ dan Neural Network sebesar $69 \%$.

Kedua penelitian tersebut menggunakan dataset sama yaitu heart failure clinical records data set yang bursumber di UCI Machine Learning Repository [11]. Namun kondisi kelas yang tidak seimbang yang terdapat dalam dataset tersebut berpengaruh terhadap akurasi pada dua penelitian tersebut masih dibawah $80 \%$. Oleh karena itu pada penelitian ini akan menggunakan metode ensemble stacking untuk mengatasi permasalahan tersebut dan meningkatkan kinerja model klasifikasi penyakit jantung.

\section{Metode PEnELITIAN}

Penelitian ini dilakukan berdasarkan tahapan penelitian yang meliputi akuisisi data, prapemrosesan data, klasifikasi, serta evaluasi sebagaimana ditunjukkan pada Gambar 1.

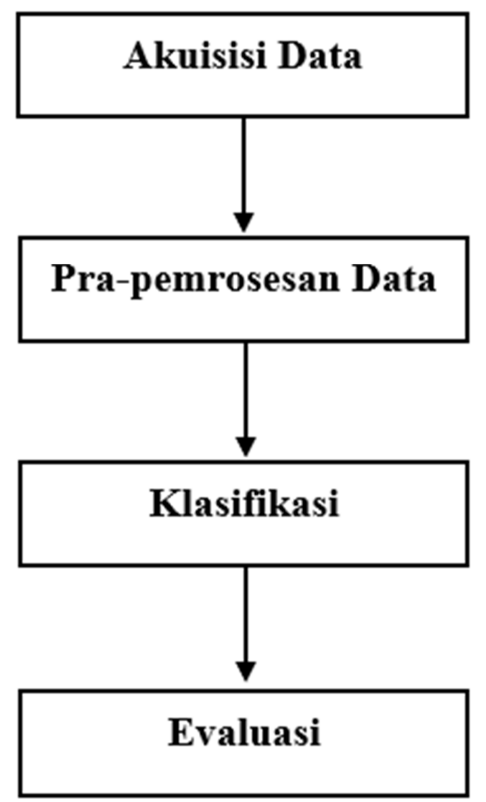

Gambar 1. Tahapan Penelitian

Tahap pertama pada penelitian ini ialah proses akuisisi data. Pada penelitian dataset yang digunakan merupakan dataset publik yang termasuk kategori benchmarking. Dataset bersumber dari repository UCI Machine Learning. Dataset yang digunakan ialah heart failure clinical records data set [11]. Heart failure clinical merupakan dataset utama yang digunakan dalam penelitian ini. Selain itu dataset ini terdiri dari 13 features, 299 instances dan 2 class/label. Jumlah instance minoritas sebesar 96 instances sedangkan jumlah kelas mayoritas sebesar 203 instances. Berikut Tabel 1 merupakan detail fitur pada dataset heart failure clinical.

Tabel 1. Detail Fitur Dataset Heart Failure Clinical

\begin{tabular}{|l|l|}
\hline \multicolumn{1}{|c|}{ Variabel } & \multicolumn{1}{c|}{ Tipe } \\
\hline Age & Numeric \\
\hline Anemia & Categorical \\
\hline High blood pressure & Categorical \\
\hline Creatine phosphokinase (CPK) & Numeric \\
\hline Diabetes & Categorical \\
\hline Ejection Fraction & Numeric \\
\hline Platelets & Numeric \\
\hline Sex & Categorical \\
\hline Serum creatine & Numeric \\
\hline Serum sodium & Numeric \\
\hline Smoking & Categorical \\
\hline Time & Numeric \\
\hline Death event (target/class/label) & Categorical \\
\hline
\end{tabular}

Tahap selanjutnya setelah akuisisi data ialah melakukan pra-pemrosesan terhadap dataset yang digunakan. Tahap pra-pemrosesan data pada umumnya meliputi beberapa hal anatara lain pengisian data yang kosong, menghilangkan duplikasi data, dan memeriksa inkonsistensi data. Biasanya data yang kosong disebabkan oleh kesalahan alat pada saat pengambilan data maupun adanya data baru yang belum ada informasinya. Pada tahap pra-pemrosesan kami melakukan pengisian missing values pada dataset. Keberadaan missing values pada dataset tentunya juga akan berpengaruh pada hasil klasifikasi dataset itu sendiri. Oleh karena itu pada tahap ini kami melakukan pengisian missing values menggunakan suatu nilai konstan. Pada data numerik missing values diganti dengan nilai rata-rata, sedangkan 
Jurnal Pseudocode, Volume VIII Nomor 1, Februari 2021, ISSN 2355-5920, e-ISSN 2655-1845 www.ejournal.unib.ac.id/index.php/pseudocode

untuk data kategorik maka missing values diganti dengan nilai modus.

Setelah tahap pra-pemrosesan data, tahap berikutnya ialah proses klasifikasi menggunakan algoritme ensemble atau meta learning. Algoritme ensemble yang dipilih ialah Stacking Algoritm. Tujuan utama menggunakan algoritme Stacking ialah sebagai solusi untuk mengatasi keberadaan ketidakseimbangan kelas yang ada pada dataset yang digunakan. Stacking merupakan salah satu algoritme ensemble, pada Gambar 3 menunjukkan algoritma stacking. $\mathrm{N}$ himpunan bagian yang berbeda dari kumpulan data pelatihan dibuat dengan menggunakan pengambilan sampel bertingkat dengan penggantian di mana proporsi relatif dari kelas yang berbeda dipertahankan di semua himpunan bagian. Setiap subset dari set pelatihan digunakan untuk menentukan kinerja pengklasifikasi pada set pelatihan. Meta-classifier dalam bentuk bobot relatif untuk masing-masing classifier dibuat dengan menetapkan bobot ke classifier yang sebanding dengan kinerjanya. Meta classifier dapat digambarkan dalam berbagai tahap dalam skenario meta-learning yang disederhanakan [12]. Berikut Gambar 2 merupakan gambaran proses kerja algoritme stacking.

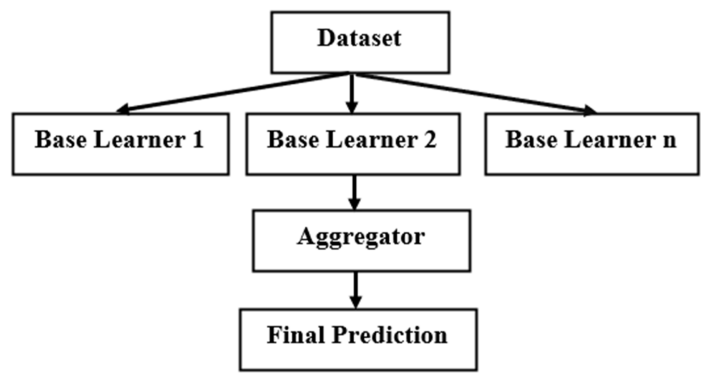

Gambar 2. Gambaran Proses Stacking

Pada penelitian ini kami menggunakan algoritme stacking dengan base learner C4.5 dan Support Vector Machine, dengan asumsi bahwa masing-masing single classifier tersebut tidak cukup baik dalam kasus imbalanced class classification. Sedangkan untuk aggregatornya menggunakan default dari stacking yaitu Logistic Regression. Pada penelitian ini proses pengujian menggunakan alat bantu python 3 dengan library sklearn dan jupyter notebook. Berikut Gambar 3 merupakan source code metode stacking yang diujikan.

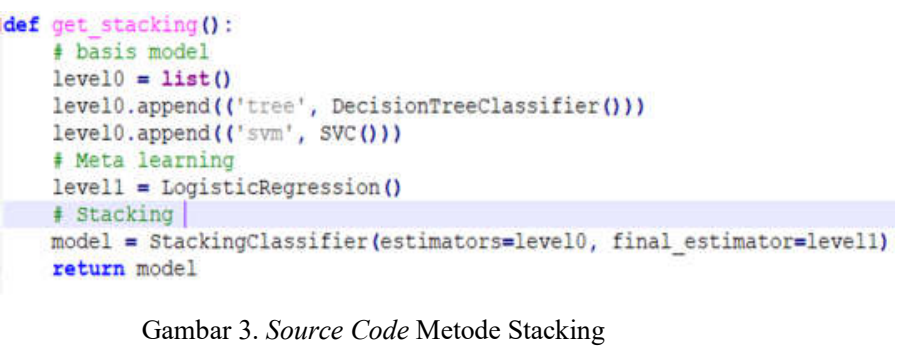

Tahap terakhir pada penelitian ini ialah melakukan evaluasi kinerja dari algoritme stacking kemudian hasilnya akan dibandingkan dengan single classifier lainnya. Hasil dari sebuah proses klasifikasi data dapat dikategorikan menjadi empat jenis yaitu:

- True Positive (TP) adalah jumlah record positif yang diklasifikasikan sebagai positif.

- False positif (FP) adalah jumlah record negatif yang diklasifikasikan sebagai positif.

- False negatif (FN) adalah jumlah record positif yang diklasifikasikan sebagai negatif,

- True negatif (TN) adalah jumlah record negatif yang diklasifikasikan sebagai negatif.

Hasil tersebut didapatkan dari confusion matrix berikut Tabel 2 merupakan Tabel confusion matrix [13].

Tabel 2. Confusion Matrix

\begin{tabular}{|c|c|c|}
\hline \multirow{2}{*}{ Aktual } & \multicolumn{2}{|c|}{ Prediksi } \\
\cline { 2 - 3 } & True & False \\
\hline True & TP & FN \\
\hline False & FP & TN \\
\hline
\end{tabular}


Jurnal Pseudocode, Volume VIII Nomor 1, Februari 2021, ISSN 2355-5920, e-ISSN 2655-1845 www.ejournal.unib.ac.id/index.php/pseudocode

Indikator evaluasi yang digunakan antara lain akurasi, true positive rate (TPR), true negative rate (TNR), geometric mean (G-Mean) dan area under curve (AUC) [14]. Berikut persamaan untuk menghitung indikator tersebut.

$$
\begin{array}{r}
\text { Akurasi }=\frac{T P+T N}{T P+T N+F P+F N} \\
T P R=\frac{T P}{T P+F N} \\
T N R=\frac{T N}{T N+F P} \\
\text { geometric mean }=\sqrt{\mathrm{TNR} x \mathrm{TPR}}
\end{array}
$$

\section{HASIL}

Pada penelitian ini kami membagi masingmasing dataset ke dalam dua bagian yaitu sebagai data training dan data testing. Skema pembagian data menggunakan skema, $80 \%$ untuk data latih model dan $20 \%$ digunakan untuk validasi model atau testing model. Pada penelitian ini algoritme yang diusulkan yaitu algoritme stacking akan dibandingkan dengan single classifier antara lain K-NN, SVM, Tree C4.5 dan Neural Network. Berikut tabel 3 merupakan hasil klasifikasi yang berupa tabel confusion matrix masing-masing algoritme.

Tabel 3. Confusion Matrix Masing-Masing Algoritme

\begin{tabular}{|l|c|c|c|c|}
\hline & TP & TN & FP & FN \\
\hline K-NN & 17 & 169 & 34 & 79 \\
\hline C4.5 & 61 & 172 & 31 & 35 \\
\hline SVM & 52 & 185 & 18 & 44 \\
\hline Neural Network & 49 & 189 & 14 & 47 \\
\hline Stacking & 60 & 182 & 21 & 36 \\
\hline
\end{tabular}

Kemudian nilai-nilai pada tabel confusion matrix tersebut akan digunakan untuk menghitung nilai evaluasi. Berikut Tabel 4 merupakan nilai hasil evaluasi algoritme menggunakan indikator yang sudah ditentukan.
Tabel 4. Confusion Matrix Masing-Masing Algoritme

\begin{tabular}{|l|c|c|c|c|c|}
\hline & K-NN & C4.5 & SVM & NN & Stacking \\
\hline Akurasi & $62 \%$ & $78 \%$ & $79 \%$ & $80 \%$ & $81 \%$ \\
\hline TPR & $18 \%$ & $64 \%$ & $54 \%$ & $51 \%$ & $63 \%$ \\
\hline TNR & $83 \%$ & $85 \%$ & $91 \%$ & $93 \%$ & $90 \%$ \\
\hline G-Mean & $38 \%$ & $73 \%$ & $70 \%$ & $69 \%$ & $75 \%$ \\
\hline AUC & $45 \%$ & $73 \%$ & $84 \%$ & $84 \%$ & $87 \%$ \\
\hline
\end{tabular}

Tabel 4 menunjukkan bahwa metode atau algoritme yang diusulkan yaitu Stacking antara Tree C4.5 dan SVM mampu menghasilkan nilai akurasi, TPR, TNR, G-Mean dan AUC yang lebih baik dibandingkan single classifier lainnya. Hal ini dikarenakan oleh keberadaan imbalanced class pada dataset. Selain itu dapat juga dilihat pada Tabel 3 menunjukkan bahwa nilai total record false atau kesalahan klasifikasi yang dihasilkan oleh algoritme stacking juga paling sedikit dibandingkan single classifier. Oleh karena itu metode atau algoritme yang diusulkan dapat menjadi solusi untuk dataset yang memiliki kondisi imbalanced class.

\section{KESIMPULAN}

Berdasarkan penelitian yang telah dilakukan menunjukkan bahwa data mining dapat digunakan sebagai solusi untuk deteksi dini penyakit jantung. Akan tetapi keberadaan imbalanced class pada dataset penyakit jantung menyebabkan kinerja single classifier menjadi tidak maksimal. Oleh karena algoritme yang diusulkan yaitu stacking dapat menjadi solusi untuk permasalahan imbalanced class. Berdasarkan pengujian yang dilakukan menunjukkan bahwa algoritme stacking mampu menghasilkan kinerja dari sisi akurasi TPR, TNR, G-Mean dan AUC yang lebih baik dibandingkan single classifier lainnya. Dengan adanya peningkatan nilai tersebut diharapkan penelitian ini mampu menjadi referensi untuk 
Jurnal Pseudocode, Volume VIII Nomor 1, Februari 2021, ISSN 2355-5920, e-ISSN 2655-1845 www.ejournal.unib.ac.id/index.php/pseudocode

pengembagan berbagai sistem yang mendukung dan memaksimalkan tingkat keberhasilan proses deteksi dini penyakit jantung menggunakan data mining.

\section{UCAPAN TERIMA KASIH}

Terima kasih kami ucapkan kepada program studi S1 Sistem Informasi dan Lembaga Penelitian Universitas Amikom Yogyakarta yang telah memberikan dukungan penuh dalam penelitian ini.

\section{REFERENSI}

[1] M. N, R. A, R. S., and S. Stang, "Karakteristik Dan Prevalensi Risiko Penyakit Kardiovaskular Pada Tukang Masak Warung Makan Di Wilayah Kerja Puskesmas Tamalanrea," J. Kesehat., vol. 11, no. 1, pp. 30-38, 2018, doi: 10.24252/kesehatan.v11i1.5029.

[2] Kemenkes RI, KMK No. 854 ttg Cardiovasular Diseases Guideline.pdf. 2009, p. 32.

[3] I. Ayu, E. Widiastuti, R. Cholidah, G. W. Buanayuda, and I. B. Alit, "Deteksi Dini Faktor Risiko Penyakit Kardiovaskuler pada Pegawai Rektorat Universitas Mataram," J. Pengabdi. Magister Pendidik. IPA, vol. 4, pp. 137-142, 2021.

[4] A. B. Wibisono and A. Fahrurozi, "Perbandingan Algoritma Klasifikasi Dalam Pengklasifikasian Data Penyakit Jantung Koroner," J. Ilm. Teknol. dan Rekayasa, vol. 24, no. 3, pp. 161-170, 2019, doi: 10.35760/tr.2019.v24i3.2393.

[5] Fadhilah Ahmad, N. H. Ismail, and Azwa Abdul Aziz, "The prediction of students' academic performance using classification data mining techniques," Appl. Math. Sci., vol. 9, no. 129, pp. 6415-6426, 2015, doi: 10.12988/ams.2015.53289.
[6] Y. Pristyanto, "Penerapan Metode Ensemble Untuk Meningkatkan Kinerja Algoritme Klasifikasi Pada Imbalanced Dataset," J. TEKNOINFO, vol. 13, no. 1, pp. 11-16, 2019, doi: 10.33365/jti.

[7] I. H. Witten, E. Frank, and M. A. Hall, Data Mining: Practical Machine Learning Tools and Techniques, 3rd ed. San Francisco, CA, USA: Morgan Kaufmann Publishers Inc., 2011.

[8] V. V. Ramalingam, A. Dandapath, and M. Karthik Raja, "Heart disease prediction using machine learning techniques: A survey," Int. J. Eng. Technol., vol. 7, no. 2.8 Special Issue 8, pp. 684-687, 2018, doi: 10.14419/ijet.v7i2.8.10557.

[9] P. S. Kohli and A. L. Regression, "Application of Machine Learning in Disease Prediction," in 2020 IEEE 5th International Conference on Computing Communication and Automation, ICCCA 2020, 2020, pp. 1-4.

[10]C. S. Wu, M. Badshah, and V. Bhagwat, "Heart disease prediction using data mining techniques," in $A C M$ International Conference Proceeding Series, 2019, pp. 711, doi: 10.1145/3352411.3352413.

[11]D. Chicco and G. Jurman, "Machine learning can predict survival of patients with heart failure from serum creatinine and ejection fraction alone," BMC Med. Inform. Decis. Mak., vol. 20, no. 1, pp. 1-16, 2020, doi: 10.1186/s12911020-1023-5.

[12]N. Chanamarn, K. Tamee, and P. Sittidech, "Stacking technique for academic achievement prediction," Int. Work. Smart Info-Media Syst. Asia (SISA 2016), no. Sisa 2016, pp. 14-17, 2016.

[13]J. Han, M. Kamber, and J. Pei, Data Mining : Concept and Techniques, Third Edit. Massachusetts: Morgan Kauffman, 2011.

[14]Q. Wang, "A hybrid sampling SVM approach to imbalanced data classification," Abstr. Appl. Anal., vol. 2014, 2014, doi: 10.1155/2014/972786. 